\title{
LANGKAH-LANGKAH DALAM MERUMUSKAN RENCANA KEPERAWATAN
}

\author{
Julia Rahma/191101040 \\ emasurya123emasurya123@gmail.com
}

\begin{abstract}
ABSTRAK
Proses keperawatan merupakan kerangka sistematis yang dilakukan dalam pemberian asuhan keperawatan untuk memenuhi reaksi dan respon individu. Proses keperawatan itu sendiri meliputi tahapan pengkajian, diagnosa keperawatan, perencanaan/intervensi, implementasi, dan evaluasi. Perencanaan merupakan tahap yang ketiga dari proses keperawatan, dalam tahap perencanaan ini berfokus kepada prioritas masalah, merumuskan tujuan dan kriteria hasil, dan intervensi. Tujuan untuk mengetahui bagaimana langkahlangkah perencanaan dalam merumuskan rencana keperawata. Metode yang digunakan adalah teknik pengumpulan data atau informasi dengan melakukan analisis, eksplorasi, kajian bebas yang relevan yang berfokus pada langkah langkah dalam merumuskan rencana keperawatan dengan menggunakan 14 referensi, jurnal dan e-book. Hasil yang diperoleh dari pembuatan jurnal ini menyatakan bahwa langkah langkah dalam merumuskan rencana keperawatan diantaranya yaitu prioritas masalah, kriteria hasil, rencana intervensi, dan pendokumentasian. Komponen-komponen tersebut sangat membantu pada proses evaluasi keberhasilan asuhan keperawatan yang telah diimplementasikan. Kesimpulan Setiap pasien memerlukan asuhan keperawatan yang baik maka perlu suatu perencanaan yang baik pula. Rencana asuhan keperawatan yang akan disusun harus mempunyai beberapa komponen, yaitu prioritas masalah, kriteria hasil, rencana intervensi, dan pendokumentasian. Komponen-komponen tersebut sangat membantu pada proses evaluasi keberhasilan asuhan keperawatan yang telah di implementasikan.
\end{abstract}

Kata Kunci : perencanaan keperawatan, proses keperawatan , asuhan keperawatan

\section{LATAR BELAKANG}

Keperawatan sebagai profesi merupakan salah satu pekerjaan dimana dalam menentukan tindakan didasari pada ilmu pengetahuan serta memiliki kertampilan yang jelas dalam keahliannya, selain itu sebagai profesi keperawatan mempunyai otonomi dalam kewenangan 
dan tanggung jawab dalam tindakan serta adanya kode etik dalam bekerjanya kemudian juga berorientasi pada pelayanan dengan melalui pemberian asuhan keperawatan kepada individu, kelompok atau masyarakat (Hidayat, 2011). Proses keperawatan merupakan kerangka sistematis yang dilakukan dalam pemberian asuhan keperawatan untuk memenuhi reaksi dan respon individu. Proses keperawatan itu sendiri meliputi tahapan pengkajian, diagnosa keperawatan, perencanaan/intervensi, implementasi, dan evaluasi. Perencanaan merupakan tahap yang ketiga dari proses keperawatan, dalam tahap perencanaan ini berfokus kepada prioritas masalah, merumuskan tujuan dan kriteria hasil, dan intervensi.

\section{TUJUAN}

Tujuan yang didapat dalam penelitian ini yaitu untuk mengetahui bagaimana langkahlangkah perencanaan dalam merumuskan rencana keperawatan.

\section{METODE}

Metode yang digunakan adalah teknik pengumpulan data atau informasi dengan melakukan analisis, eksplorasi, kajian bebas yang relevan yang berfokus pada langkah langkah dalam merumuskan rencana keperawatan dengan menggunakan 14 referensi, jurnal dan e-book.

\section{HASIL}

Dari hasil penelitian menunjukkan bahwa langkah-langah dalam merumuskan rencana keperawatan yang dapat dilakukan yaitu :

1. Menentukan prioritas masalah

2. Menuliskan tujuan dan kriteria hasil

3. Memilih rencana tindakan atau intervensi keperawatan.

\section{PEMBAHASAN}

Proses keperawatan merupakan kerangka sistematis yang dilakukan dalam pemberian asuhan keperawatan. menurut Muhlisin (2011) proses keperawatan adalah salah satu metoda efektif pemecahan masalah yang dilakukan perawat terhadap klien dengan pendekatan metodologi ilmiah an untuk memenuhi reaksi dan respon individu. Asuhan keperawatan dapat dipertanggung jawabkan berdasarkan substansi ilmiah yaitu logis, sistimatis, dinamis 
dan terstruktur. Sedangkan menurut Dermawan (2012) proses keperawatan adalah aktivitas yang mempunyai maksud yaitu praktik keperawatan yang dilakukan dengan cara yang sistematik. Selama melaksanakan proses keperawatan, perawat menggunakan dasar pengetahuan yang komprehensif untuk mengkaji status kesehatan klien, membuat penilaian yang bijaksana dan mendiagnosa, mengidentifikasi hasil akhir kesehatan klien dan merencanakan, menerapkan dan mengevaluasi tindakan keperawatan yang tepat guna mencapai hasil akhir tersebut . Proses keperawatan adalah suatu metode ilmiah yang sistematis dan terorganisir dalam memberikan asuhan keperawatan pada pasien yang berfokus pada respon individu terhadap gangguan kesehatan yang dialami (Manurung, 2011).

Adapun tujuan utama proses keperawatan menurut Christensen dan Kenney (2009) adalah:

a. Memberikan metode sistematis bagi praktek keperawatan.

b. Memudahkan pendokumentasian data, diagnosis, rencana, respon klien, dan evaluasi.

c. Mengevaluasi efektivitas dan efisiensi asuhan.

d. Memberikan kemungkinan asuhan yang berkesinambungan dan mengurangi kelalaian

e. Mengindividualisasikan keikutsertaan klien dalam perawatan.

f. Meningkatkan kreativitas dan fleksibilitas dalam praktik keperawatan.

Dalam setiap tindakannya perawat harus berpegang teguh terhadap pedoman proses keperawatan. Sebab jika perawat tidak menerapakn tindakan sesuai proses keperawatan dapat menimbulkan kerugian bagi pasien dan keluarga. Seperti kerugian materi bahkan berujung kematian. Dengan dibekali pengetahuan dan tindakan yang terampil perawat akan menjadi lebih profesional dalam melakukan tindakan. Sebagai pemberi asuhan keperawatan, perawat harus memberikan pelayanan sesuai dengan kebutuhan pasien. Menurut Hidayat (2010) pemberi asuhan keperawatan adalah tugas perawat pelaksana. Hal ini diperkuat dengan penelitian Pratiwi \& Utami (2010) perawat pelaksana bertugas memberikan asuhan keperawatan, membantu penyembuhan, membantu memecahkan masalah pasien dibawah pengawasan dokter atau kepala ruang. Perawat sebagai perencana pemulangan harus mampu mengkaji hingga mengevaluasi kesinambungan asuhan keperawatan, memberikan tindakan khusus untuk mengajarkan dalam mempertahankan atau memulihkan kembali kondisi pasien secara optimal dan bertanggung jawab untuk memastikan bahwa semua informasi 
yang sesuai telah disediakan untuk orang-orang yang akan terlibat dalam perawatan pasien, termasuk keluarganya (Pemila, 2009).

Proses keperawatan meliputi 5 tahapan yaitu pengkajian ,diagnosa, perencanaan/intervensi, implementasi, dan evaluasi. Lima tahapan inilah yang sampai saat ini digunakan sebagai langkah-langkah proses keperawatan ( Deswani, 2011). Dimana setiap tahapan ini berakaitan erat dan harus dilakukan. Namun, peneliti akan membahas mengenai tahap perencanaan. Sedangkan menurut Manurung (2011), perencanaan keperawatan adalah rencana tindakan keperawatan tertulis yang menggambarkan masalah kesehatan pasien, hasil yang akan diharapkan, tindakantindakan keperawatan dan kemajuan pasien secara spesifik. Perencanaan keperawatan adalah bagian dari fase pengorganisasian dalam proses keperawatan sebagai pedoman untuk mengarahkan tindakan keperawatan dalam usaha membantu, meringankan, memecahkan masalah atau untuk memenuhi kebutuhan pasien (Setiadi, 2012).

Dalam tahap perencanaan ini terdapat langkah-langkah penyusanannya yaitu :

\section{Menentukan Prioritas Masalah}

Pada tahap pengkajian perawat menemukan banyak masalah pada pasien dan didapatkan diagnosanya. Kemudian perawat mengurutkan diagnosa tersebut dari prioritas tertinggi, sedang, dan rendah. Prioritas tertinggi ini merupakan situasi yang mengancam nyawa pasien seperti bersihan jalan nafas. Sedangkan prioritas sedang merupakan situasi yang tidak terlalu darurat seperti persobal higiene. Serta prioritas rendah memuat masalah yang tidak terlalu spesifik contohnya masalah kebutuhan pasien. Pengurutan prioritas tersebut berpengaruh terhadap persepsi pasien, untuk itu perawat harus menanyakan kepada pasien mengenai apa yang dirasakannya.

\section{Menuliskan Tujuan dan Kriteria Hasil Tujuan}

perawatan adalah hasil yang diinginkan dari asuhan keperawatan yang diharapkan dapat dicapai bersama pasien serta direncanakan untuk mengurangi masalah yang telah diidentifikasi dalam diagnosis keperawatan (Manurung, 2011). Kriteria hasil ini memuat tujuan dan sasaran yang fokus dan dapat diukur hasil akhir dari asuhan keperawatannya. Tujuan dan kriteria hasil ini meliputi hasil kolaborasi tenaga medis seperti (dokter, ahli gizi, farmasi, radiologi, dan pekerja sosial lainnya). Komponen penyusunan tujuan dan kriteria hasil yaitu :

a. Subjek, menunjukkan siapa yang mencapai target kriteria hasil 
b. Kata kerja yang dapat diukur, menunjukkan tindakan, persepsi, dan tingkah laku klien yang dapat diukur (dilihat, dengar, raba)

c. Hasil, menunjukkan respon fisiologis, psikologis, dan gaya hidup klien terhadap intervensi. Diharapkan klien dapat merubah kondisi yang spesifik terhadap asuhan keperawatan tertentu.

d. Kriteria, mengukur kemajuan dengan mencapai target hasil yang diperlukan untuk menyelesaikan hasil akhir.

e. Target waktu, menunjukkan periode yang diharapkan dalam mencapai kriteria hasil. Batasan waktu membantu perawat alam evaluasi.

\section{Memilih rencana tindakan atau intervensi keperawatan.}

(1) Tindakan keperawatan harus aman bagi pasien.

(2) Tindakan keperawatan harus sejalan dengan tindakan pengobatan.

(3) Tindakan keperawatan harus didasari prinsip dan pengetahuan yang digabungkan dari pendidikan dan pengalaman sebelumnya.

(4) Tulis sekumpulan tindakan keperawatan untuk mencapai setiap tujuan.

(5) Pilih satu kumpulan tindakan keperawatan yang kiranya cocok dengan sikap yang disebutkan dalam pernyataan tujuan.

(6) Tindakan keperawatan harus realistis.

(7) Tindakan keperawatan harus penting bagi peningkatan kesehatan pasien dan sejalan dengan tujuan serta nilai perseorangan pasien.

(8) Gunakan pasien sebagai sumber-sumber dalam memilih tindakan keperawatan.

(9) Tulis tindakan keperawatn secara berurutan.

Perawat diharapkan memahami tentang konsep proses keperawatan dan mampu menerapkan serta menyusunannya dalam sebuah dokumen status kesehatan klien. Kemampuan perawat dalam menerapkan proses keperawatan dalam asuhannya sudah tidak dapat ditawar lagi apabila ia meyakini bahwa asuhannya adalah asuhan yang profesional (Rohmah, $\mathrm{N}$ dan Walid, S. 2009). Perawat dituntut untuk memberikan pelayanan dengan kualitas yang bermutu sehingga dapat meningkatkan kepuasan pasien. Menurut Efendi \& Makhfudli (2009) layanan keperawatan yang bermutu adalah layanan keperawatan yang senantiasa berupaya memenuhi harapan klien sehingga klien akan selalu puas terhadap pelayanan yang diberikan perawat.

\section{PENUTUP}


Dari hasil penelitian yang telah dilakukan dapat disimpulkan bahwa proses keperawatan penting diterapkan dalam asuhan keperawatan. Sehingga meningkatkan profesionalitas dan kinerja yang lebih bermutu dan memberikan kepuasan terserniri bagi pasien. Dimana dalam proses keperawatan terdapat tahap perencanaan, adapun langkah-langkah perencanaan dalam proses keperawatan yaitu :

1. Menentukan prioritas masalah

2. Menuliskan tujuan dan kriteria hasil

3. Memilih rencana tindakan atau intervensi keperawatan

Bagi perawat untuk terus melakukan pelatihan mengenai penerapan proses keperawatan di Rumah Sakit terhadap pasien guna memberikan pelayanan yang bermutu.

\section{DAFTAR PUSTA}

Dermawan, D. (2012). Proses Keperawatan Penerapan Konsep \& Kerangka Kerja (1st ed.). Yogyakarta: Gosyen Publishing.

Deswani (2011). Hubungan antara Kelengkapan Dokumentasi Keperawatan dengan Mutu Pelayanan Keperawatan di Ruang Melati RS Margono Soekarjo. http:// digilib.ump.ac.id/files/disk1/18/jhptu mp-a-dhianwahyu- 879-1-babi.pdf diakses tanggal 15 Desember 2019.

Hidayat, A. Alimul. (2010). Metode Penelitian Kesehatan Paradigma Kuantitatif. Jakarta: Heat Books.

Kasim, M., Abdurraouf, M. (2016). Peningkatan Kualitas Pelayanan dan pen dokumentasikan Asuhan Keperawatan Dengan Metode TIM. Nurseline Journal. Vol 1. No 1. 5.

Manurung, S. (2011). Buku ajar keperawatan maternitas asuham keperawatan intranatal. Jakarta : Trans Info Media.

Medika. Hidayat, A. A. (2011). Pengantar Konsep Dasar Keperawatan. Jakarta: Salemba Medika.

Muhlisin, A. 2011. Dokumentasi Keperawatan. Penerbit Yogyakarta : Gosyen Publishing. Mutaqqin, Arif. (2010). Pengkajian Keperawatan Aplikasi Pada Praktik Klinik. Jakarta: Salemba Medika

Pratiwi, A dan Utami, Y. W. (2010). Pembinaan dan Pendampingan Pimpinanan Keperawatan dalam Melaksanakan Peran dan Fungsi Manajemen pada Kepala 
Ruang di RS PKU Muhammadiyah Surakarta. Jurnal Keperawatan, Vol. 13 (1) pp. $37-47$

Setiadi. 2012. Konsep \& Penulisan Dokumentasi Asuhan Keperawatan Teori dan Praktik. Yogyakarta : Graha Ilmu

Butar-Butar, J., \& Simamora, R. H. (2016). Hubungan Mutu Pelayanan Keperawatan dengan Tingkat Kepuasan Pasien Rawat Inap di RSUD Pandan Kabupaten Tapanuli Tengah. Jurnal Ners Indonesia, 6(1), 50-63.

Simamora, R. H. (2005). Hubungan Persepsi Perawat Pelaksana Terhadap Penerapan Fungsi Pengorganisasian Yang Dilakukan Oleh Kepala Ruangan Dengan Kinerjanya Diruang Rawat Inap RSUD Koja Jakarta Utara (Doctoral dissertation, Tesis FIK UI, Tidak dipublikasikan). 